\title{
Are CD68 and Factor VIII-RA Expression Different in Central and Peripheral Giant Cell Granuloma of Jaw: An Immunohistochemical Comparative Study
}

\author{
Soudabeh SARGOLZAEI, Nasim TAGHAVI, Farzaneh POURSAFAR
}

Department of Oral Pathology, Shahid Beheshti University of Medical Sciences, School of Dentistry, TEHRAN, IRAN

\begin{abstract}
Objective: Central giant cell granuloma and peripheral giant cell granuloma of the jaw and oral cavity are identical in histopathologic features, although they are different in pathogenesis and clinical behavior. The aim of present study was to compare CD 68 and factor VIII related antigen (VIII-RA) immunoreactivity in central giant cell granuloma and peripheral giant cell granuloma to determine the biologic nature and clinical behavior of these lesions which may lead to a better or new treatment modality.

Material and Method: CD68 and factor VIII-RA expression were examined immunohistochemically in 22 cases of central giant cell granuloma (10 aggressive and 12 non- aggressive ) and 19 cases of peripheral giant cell granuloma. The Kruskal-Wallis test followed by the Dunn test was used for data analysis.

Results: CD68 expression was observed in approximately 100\% of multinucleated giant cells and 50\% of mononuclear cells. Overexpression of factor VIII-RA in the endothelial cells of capillary like vessels in the periphery of the lesions was prominent. A statistical significant difference for CD68 intensity score in mononuclear cells among three groups $(\mathrm{P}=0.016)$ was observed. Indeed, factor VIII-RA intensity score in the endothelial cells of central giant cell granuloma and peripheral giant cell granuloma showed significant difference $(\mathrm{P}=0.004)$.

Conclusion: These findings support the histiocyte/macrophage nature of multinucleated giant cells and mononuclear cells. Overexpression and high intensity score of CD68 in mononuclear cells and the high intensity score of factor VIII-RA in endothelial cells represent less aggressive behavior in central giant cell granuloma.
\end{abstract}

Key Words: Giant cell granuloma, CD68, Factor VIII-RA, Jaw

\section{INTRODUCTION}

Central giant cell granuloma (CGCG) is an intraosseous lesion of unknown etiology. There is much debate regarding whether this entity presents a reactive process or a benign neoplasm. CGCG is classified as aggressive and nonaggressive based upon radiographic criteria and clinical features $(1,2)$. The lesions that recur after treatment or are greater than $5 \mathrm{~cm}$ in size are considered aggressive types. Tooth displacement, cortical perforation or root resorption are also radiologic criteria of aggressive lesions. Nonaggressive lesions exhibit few or no symptoms with slow growth and constitute most of the cases $(3,4)$. Histologically, CGCG is characterized by multinucleated giant cells (MGCs) in a fibroblastic vascularized background $(5,6)$. Some evidence indicates the histiocyte/macrophage nature of MGCs, while others suggest an osteoclastic phenotype (7-11). Fibroblasts make up the proliferative component of CGCG because they express proteins related to the cell cycle. They are also responsible for recruitment and retention of monocytes and subsequent transformation of

(Turk Patoloji Derg 2018, 34:49-56)

Received : 28.10.2016 Accepted : 06.05.2017
MGCs (7-10). Interestingly, there are no reliable markers to predict the prognosis and clinical behavior of CGCG.

Peripheral giant cell granuloma (PGCG) is a relatively common extraosseouss reactive lesion of the oral cavity. Inflammatory or developmental reactions in the periosteum or periodontal ligament have been proposed as possible etiologic factors of PGCG. PGGG bears microscopic resemblance to CGCG despite different clinical features. MGCs presence in PGCG remains unclear $(12,13)$.

CD68 is a transmembrane glycoprotein with an unknown function. At a very low dose, it is expressed in most cell types but strongly expressed by tissue macrophages, human monocytes, osteoclasts and histiocytes $(7,8)$. CD 68 expression in MGCs and mononuclear cells (MCs) of giant cell lesions has been reported previously (11).

Factor VIII Related antigen (VIII-RA), the most commonly recommended endothelial cell marker, is produced by endothelial cells and megakaryocytes $(14,15)$. The literature evidenced a direct activity of factor VIII-RA complex on

Correspondence: Nasim TAGHAVI

Shahid Beheshti University of Medical Sciences, School of Dentistry

Department of Oral Pathology, TEHRAN, IRAN

E-mail: nasim.taghavi@yahoo.com Phone: +98912 1815387 
osteoclastogenesis and a role in bone remodeling or bone damage (16). Therefore, the objective of this study was to compare the CD68 and factor VIII-RA immunoreactivity in aggressive CGCG, non-aggressive CGCG and PCGG of the jaw and oral cavity to determine the biologic nature and clinical behavior of these lesions which may lead to a better or new treatment modality.

\section{MATERIALS and METHODS}

In this retrospective study, 22 paraffin-embedded tissue samples of CGCG (10 aggressive, 12 non-aggressive) and 19 samples of PGCG were collected from the archive of the department of Oral Pathology, Shahid Beheshti University of Medical Sciences, Tehran, Iran.

The CGCG classification into aggressive and nonaggressive was conducted based on Choung and Kanban's classification system (3).

Clinical information on each case including age, gender and location were determined. Root resorption, rapid growth, tooth displacement, cortical thinning, recurrence, size and perforation were obtained from medical records to classify CGCGs. Cases without complete data and inadequate paraffin-embedded tissue were excluded from the study.

Immunohistochemistry: $3 \mu \mathrm{m}$ sections of routinely processed paraffin-embedded blocks were cut and mounted on adherent glass slides. The sections were deparaffinized in xylene and rehydrated in graded ethanol series and then treated with $3 \%$ hydrogen peroxide. Microwave pretreatment for 15 minutes in citrate buffer ( $\mathrm{PH}$ 6.0, 10 $\mathrm{mM}$ ) was performed to retrieve antigen. The sections were then incubated for one hour at room temperature with primary antibodies: 1) CD68- mouse monoclonal antibody (KP1, Dako, Denmark), 2) factor VIII-mouse monoclonal antibody (F8/86, Dako, Denmark). This was followed by incubation with secondary antibody (Dako Envision ${ }^{\mathrm{TM}}$ ) for 30 minutes and finally diamiobenzidine (DAB) for 3-5 minutes. The slides were counterstained with Mayer's hematoxylin.

Lymph node germinal center and blood vessels in the periphery of the lesions were used as positive control for CD68 and factor VIII-RA, respectively. In the negative control, non-immune serum was used instead of primary antibody.

CD68 and factor VIII-RA expression were assessed in multinucleated giant cells, mononuclear cells and endothelial cells in eight high power (x400) fields. Each field was evaluated for the proportion of stained cells and the staining intensity.

Staining intensity was graded as: 0 , negative; 1 , light staining; 2, moderate staining; 3 , intense staining. The proportion score of stained cells for CD68 and factor VIIIRA was assessed as: 0 , no stained cells; $1,<25 \%$ stained cells; $2,25-50 \%$ stained cells; $3,>50 \%$ stained cells $(17,18)$.

The data were stored and analyzed with the SPSS 21 Software Package (SPSS, Inc, Chicago, IL, USA). Data analysis was performed using the Kruskal-Wallis test followed by the Dunn test. Significance was established at $\mathrm{P}$-value $<0.05$.

\section{RESULTS}

In total, 22 cases of CGCG and 19 cases of PGCG were studied. The average age in non-aggressive CGCG and aggressive CGCG, and PGCG were $24.52 \pm 11.72,22.67 \pm$ 14.42 and $40.11 \pm 17.36$, respectively. All groups occurred more often in the mandible than the maxilla (Table I). Eight (66.6\%) cases of non-aggressive CGCG presented as painless swelling and $4(33.4 \%)$ cases were asymptomatic. Clinical features of aggressive CGCG cases are given in Table II.

Table I: Demographic details of patients with central giant cell granuloma and peripheral giant cell granuloma

\begin{tabular}{lcccc}
\hline Parameter & $\begin{array}{c}\text { Non-aggressive } \\
\text { CGCG }(\mathbf{n = 1 2})\end{array}$ & $\begin{array}{c}\text { Aggressive CGCG } \\
(\mathbf{n = 1 0})\end{array}$ & PGCG (n=19) & P-value \\
\hline Age $($ mean \pm SD) & $24.52 \pm 11.72$ & $22.76 \pm 14.42$ & $40.11 \pm 17.36$ & 0.006 \\
\hline Gender & & & & 0.76 \\
$\quad$ Female & $10(83.3 \%)$ & $5(50 \%)$ & $8(42.1 \%)$ & \\
$\quad$ Male & $2(16.6 \%)$ & $5(50 \%)$ & $11(57.9 \%)$ & 0.176 \\
\hline Location & & & & $16(84.2 \%)$ \\
$\quad$ Mandible & $8(66.6 \%)$ & $5(50 \%)$ & $3(15.8 \%)$ & \\
Maxilla & $4(33.3 \%)$ & $4(40 \%)$ & $0(0 \%)$ & \\
Mandible \& maxilla & $0(0 \%)$ & $1(10 \%)$ & & \\
\hline
\end{tabular}

CGCG: Central giant cell granuloma, PGCG: Peripheral giant cell granuloma 
Immunohistochemical evaluation of the three groups examined showed a positive reaction for both CD68 and factor VIII -RA. The MGCs expressed CD68 in all cases as cytoplasmic reactivity, high proportion score (score III) and intense staining (Figure 1). CD68 was detected

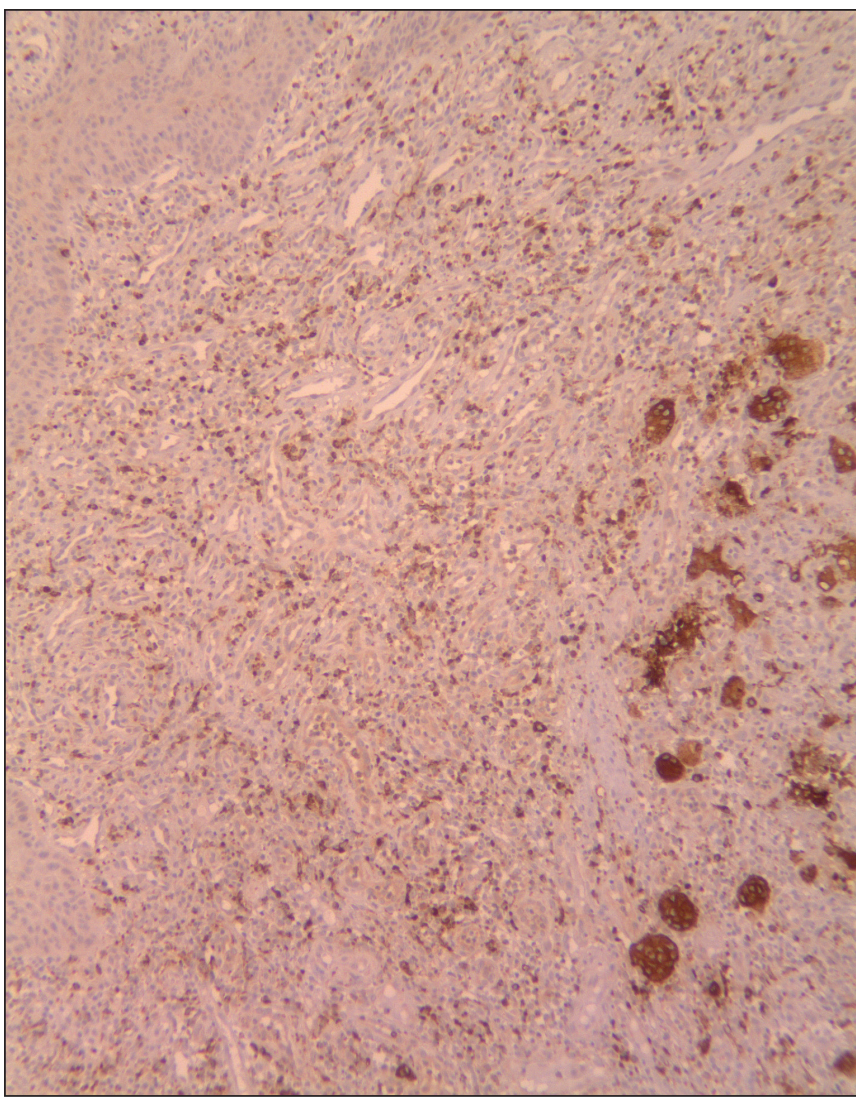

Figure 1: CD68 stained multinucleated giant cells and mononuclear cells in peripheral giant cell granuloma (CD68; x100).

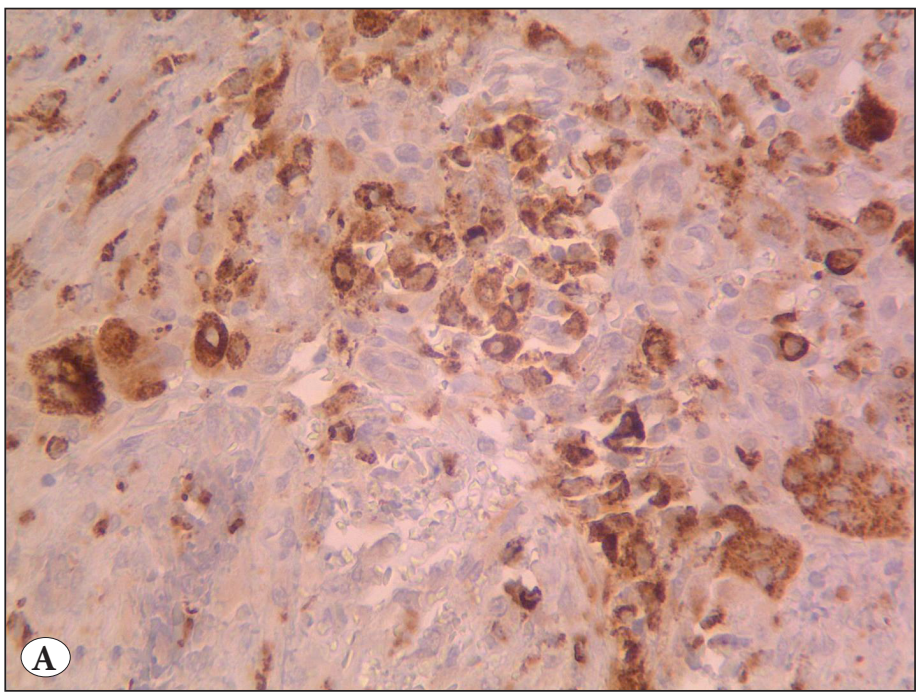

in some of MCs and endothelial cells (Figure 2,3A,B) of all groups (Table III). Factor VIII-RA immunoreactivity was observed in MGCs, MCs and endothelial cells of all categories. Notably, the expression was less prominent than CD68. With respect to factor VIII-RA in MGCs, a score of 2 was obtained in most PGCG cases (36.8\%), whereas a predominance of negative staining and score of 2 were observed in both groups of CGCG (Table IV).

The analysis of factor VIII-RA expression in MCs revealed no reactivity in most cases of the groups. On the other hand, positivity of factor VIII-RA in endothelial cells presented a discrete predominance of score 0 and score 2 in all groups (Figure 4,5). Immunoreactivity was more remarkable at the periphery of the lesions especially in PGCG. Data analysis

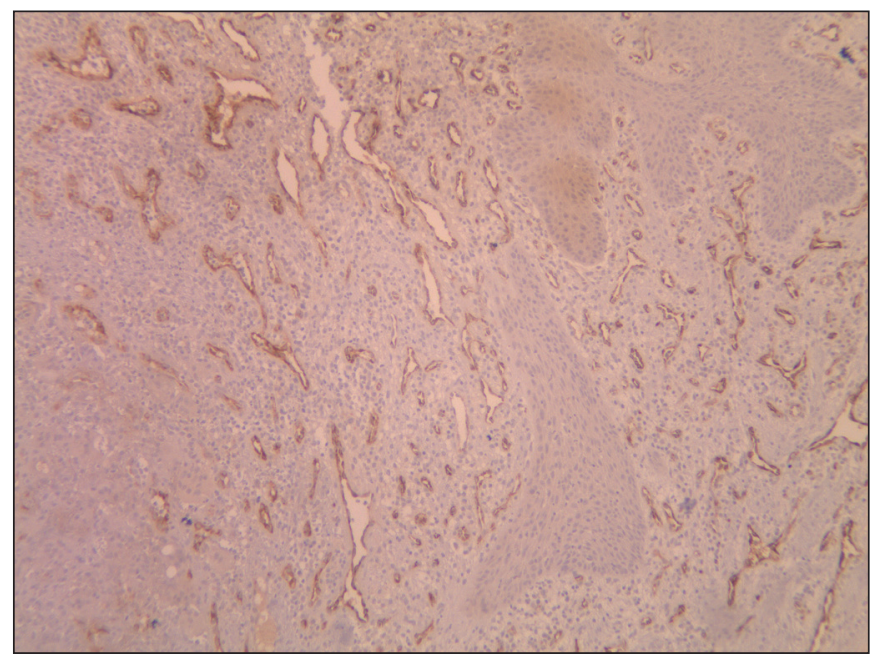

Figure 2: CD68 stained endothelial cells in peripheral giant cell granuloma(CD68; x100).

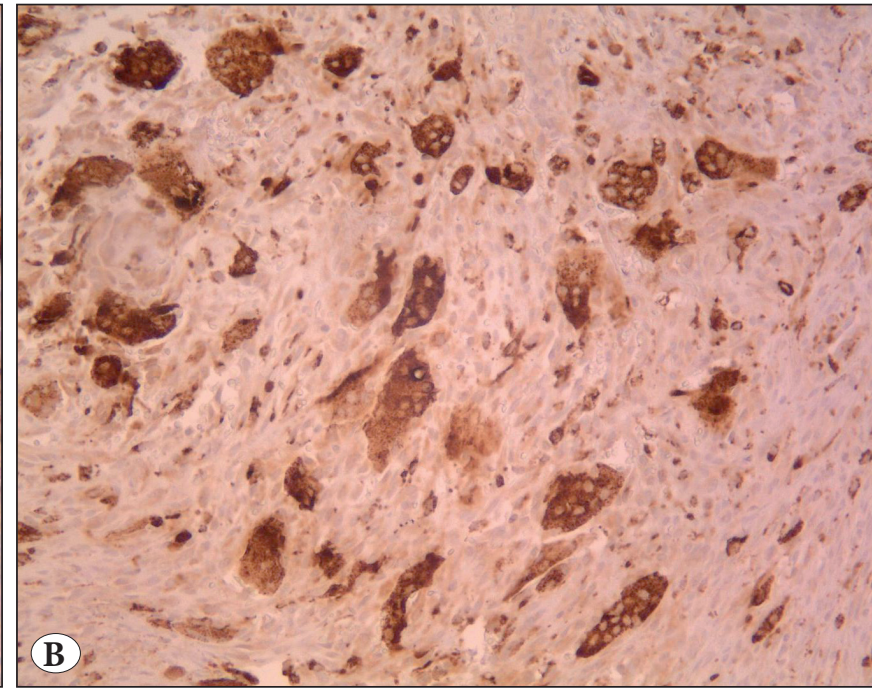

Figure 3: CD68 stained A) mononuclear cells, B) multinucleated giant cells in central giant cell granuloma (CD68; x200). 
demonstrated no significant difference among groups regarding the CD68 and factor VIII-RA expression by MGCs ( $\mathrm{p}>0.05)$.

The Kruskal-Wallis analysis showed a significant difference in CD68 intensity score in MCs among groups $(\mathrm{P}=0.016)$, with a higher intensity score observed in non-aggressive CGCG (Table V). Pairwise comparison of CD68 intensity score of MCs using the Dunn test showed significant difference between aggressive and non-aggressive CGCG $(\mathrm{p}=0.045)$. No significant difference was seen between aggressive CGCG and PGCG. The percentage of CD68 positive MCs was less in aggressive CGCG compared with the non-aggressive type. However, the difference was not significant $(p>0.05)$. CD68 positive endothelial cells were statistically significantly higher in PGCG than CGCG

Table II: Clinical Features of aggressive central giant cell granuloma cases

\begin{tabular}{cl}
\hline Case & Clinical features \\
\hline 1 & Cortical perforation, size $>5 \mathrm{~cm}$, paresthesia \\
\hline 2 & Size $>5 \mathrm{~cm}$, recurrence \\
\hline 3 & Size $>5 \mathrm{~cm}$, cortical perforation \\
\hline 4 & Cortical perforation, recurrence \\
\hline 5 & Cortical perforation, size $>5 \mathrm{~cm}$ \\
\hline 6 & $\begin{array}{l}\text { Cortical perforation, size }>5 \mathrm{~cm}, \text { root resorption, } \\
\text { tooth displacement }\end{array}$ \\
\hline 7 & $\begin{array}{l}\text { Cortical perforation, rapid growth, tooth } \\
\text { displacement, recurrence }\end{array}$ \\
\hline 8 & Size $>5 \mathrm{~cm}$, Cortical perforation \\
\hline 9 & $\begin{array}{l}\text { Root resorption, tooth displacement, cortical } \\
\text { perforation }\end{array}$ \\
\hline 10 & Cortical perforation, recurrence, rapid growth \\
\hline &
\end{tabular}

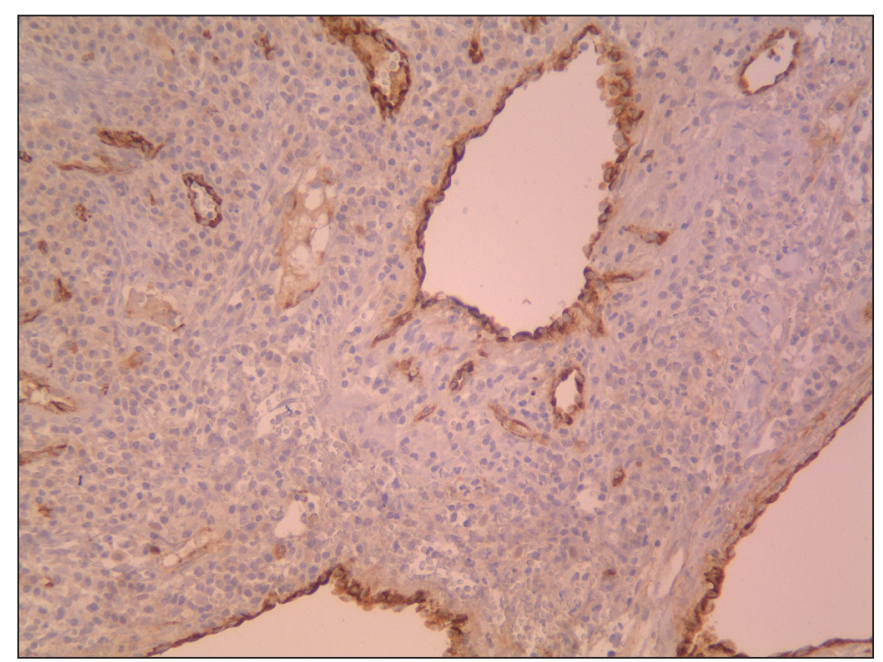

Figure 4: Factor VIII-RA stained endothelial cells in central giant cell granuloma (Factor VIII-RA; x200) $(\mathrm{p}=0.016)$ (Table VI), but no difference between aggressive and non-aggressive CGCG was found ( $\mathrm{p}=0.838$ ). Regarding the overall expression of factor VIII-RA, data analysis showed a significantly higher intensity score in endothelial cells of PGCG ( $\mathrm{p}=0.004)$ (Table VII).

\section{DISCUSSION}

Despite histochemistry, immunohistochemistry and ultrastructure studies focused on giant cell lesions of the jaw and oral cavity, the pathogenesis and nature of these lesions are still elusive. Neoplastic, reactive, inflammatory and proliferative vascular processes have been proposed $(3,19)$. Many believe that prominent MGCs are a reactive component and have phagocyte, osteoclast or endothelial cell origin $(11,19)$. The stromal MCs are mostly spindle cells with fibroblastic/myofibroblastic and endothelial differentiation that is responsible for the proliferative activity of the lesions (20-23).

To our knowledge, this is the first study to examine and compare CD68, a specific macrophagic/histiocytic marker, and factor VIII-RA, a specific endothelial marker, in aggressive CGCG, non-aggressive CGCG and PGCG.

Our results showed CD68 expression in approximately $100 \%$ of MGCs as well as a fraction of MCs in the three groups studied. This suggests a histiocyte/macrophage origin for some of the cellular components and an important role played by stromal MCs in MGC development through fusion, which is consistent with previous studies (12,24-26). Of note, the presence of functional characteristic osteoclast like bone resorption, growth inhibition by calcitonin, and expression of osteoclast markers (TRAP, MB1) in MGCs confirm the osteoclastic phenotype of these cells $(10,11$, 21,27).

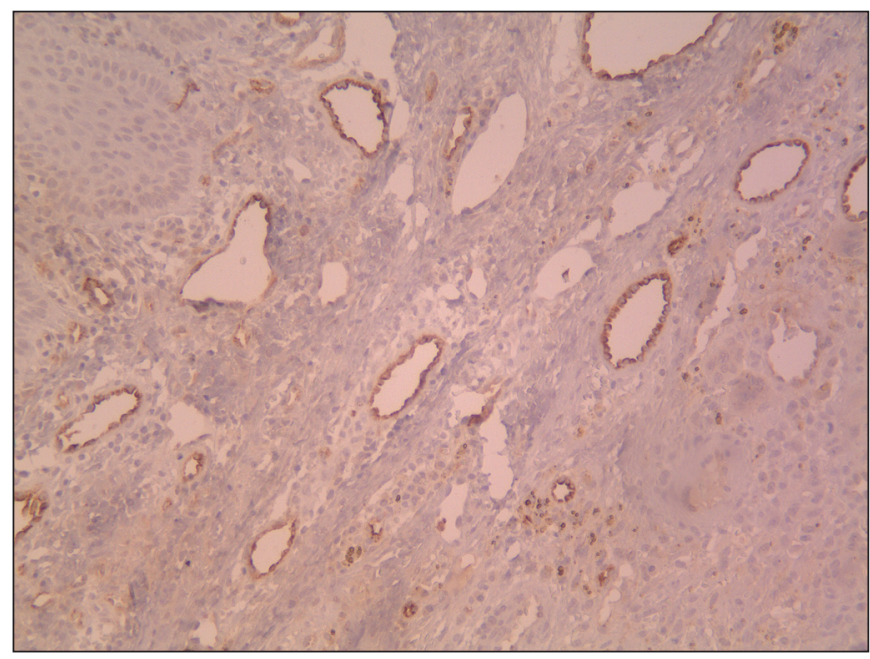

Figure 5: Factor VIII-RA stained endothelial cells in peripheral giant cell granuloma (Factor VIII-RA; x200) 
Table III: Distribution of CD 68 proportion score and intensity score among groups

\begin{tabular}{|c|c|c|c|c|c|c|c|c|}
\hline \multirow{2}{*}{ Groups } & \multicolumn{4}{|c|}{ Proportion score (n, \%) } & \multicolumn{4}{|c|}{ Intensity score (n, \%) } \\
\hline & $\mathbf{0}$ & 1 & 2 & 3 & $\mathbf{0}$ & 1 & 2 & 3 \\
\hline \multicolumn{9}{|l|}{ Aggressive CGCG (n=10) } \\
\hline Multinucleated giant cell & $0(0 \%)$ & $0(0 \%)$ & $0(0 \%)$ & $10(100 \%)$ & $0(0 \%)$ & $0(0 \%)$ & $0(0 \%)$ & $10(100 \%)$ \\
\hline Mononuclear cell & $3(30 \%)$ & $4(40 \%)$ & $2(20 \%)$ & $1(10 \%)$ & $3(30 \%)$ & $2(20 \%)$ & $5(50 \%)$ & $0(0 \%)$ \\
\hline Endothelial cell & $3(30 \%)$ & $4(40 \%)$ & $2(20 \%)$ & $1(10 \%)$ & $2(20 \%)$ & $2(20 \%)$ & $6(60 \%)$ & $0(0 \%)$ \\
\hline \multicolumn{9}{|c|}{ Non-aggressive CGCG(n=12) } \\
\hline Multinucleated giant cell & $0(0 \%)$ & $0(0 \%)$ & $0(0 \%)$ & $12(100 \%)$ & $0(0 \%)$ & $0(0 \%)$ & $0(0 \%)$ & $12(100 \%)$ \\
\hline Mononuclear cell & $0(0 \%)$ & $6(50 \%)$ & $6(50 \%)$ & $0(0 \%)$ & $0(0 \%)$ & $1(8.3 \%)$ & $9(75 \%)$ & $2(16.7 \%)$ \\
\hline Endothelial cell & $5(41.7 \%)$ & $6(50 \%)$ & $1(8.3 \%)$ & $0(0 \%)$ & $2(16.7 \%)$ & $2(16.7 \%)$ & $7(58.3 \%)$ & $1(8.3 \%)$ \\
\hline \multicolumn{9}{|c|}{ Peripheral giant cell granuloma $(n=19)$} \\
\hline Multinucleated giant cell & $0(0 \%)$ & $0(0 \%)$ & $0(0 \%)$ & $19(100 \%)$ & $0(0 \%)$ & $0(0 \%)$ & $0(0 \%)$ & $19(100 \%)$ \\
\hline Mononuclear cell & $3(15.8 \%)$ & $5(26.3 \%)$ & $6(31.6 \%)$ & $5(26.3 \%)$ & $2(10.5 \%)$ & $9(47.4 \%)$ & $7(36.8 \%)$ & $1(5.3 \%)$ \\
\hline Endothelial cell & $1(5.3 \%)$ & $9(47.4 \%)$ & $5(26.3 \%)$ & $4(21.1 \%)$ & $0(0 \%)$ & $7(36.8 \%)$ & $12(63.2 \%)$ & $0(0 \%)$ \\
\hline
\end{tabular}

CGCG: Central giant cell granuloma

Table IV: Distribution of VIII-RA Proportion score and intensity score among groups

\begin{tabular}{|c|c|c|c|c|c|c|c|c|}
\hline \multirow{2}{*}{ Groups } & \multicolumn{4}{|c|}{ Proportion score $(\mathrm{n}, \%)$} & \multicolumn{4}{|c|}{ Intensity score (n, \%) } \\
\hline & $\mathbf{0}$ & 1 & 2 & 3 & $\mathbf{0}$ & 1 & 2 & 3 \\
\hline \multicolumn{9}{|l|}{ Aggressive CGCG $(\mathrm{n}=10)$} \\
\hline Multinucleated giant cell & $5(50 \%)$ & $1(10 \%)$ & $2(20 \%)$ & $2(20 \%)$ & $4(40 \%)$ & $3(30 \%)$ & $3(30 \%)$ & $0(0 \%)$ \\
\hline Mononuclear cell & $7(70 \%)$ & $0(0 \%)$ & $1(10 \%)$ & $2(20 \%)$ & $4(40 \%)$ & $5(50 \%)$ & $1(10 \%)$ & $0(0 \%)$ \\
\hline Endothelial cell & $6(60 \%)$ & $1(10 \%)$ & $2(20 \%)$ & $1(10 \%)$ & $4(40 \%)$ & $5(50 \%)$ & $1(10 \%)$ & $0(0 \%)$ \\
\hline \multicolumn{9}{|l|}{ Non-aggressive CGCG $(\mathrm{n}=12)$} \\
\hline Multinucleated giant cell & $3(25 \%)$ & $2(16.7 \%)$ & $5(41.07 \%)$ & $2(16.7 \%)$ & $1(8.3 \%)$ & $6(50 \%)$ & $5(41.07 \%)$ & $0(0 \%)$ \\
\hline Mononuclear cell & $8(66.7 \%)$ & $2(16.7 \%)$ & $2(16.7 \%)$ & $0(0 \%)$ & $7(58.3)$ & $4(33.3 \%)$ & $1(8.6 \%)$ & $0(0 \%)$ \\
\hline Endothelial cell & $6(50 \%)$ & $1(8.3 \%)$ & $3(25 \%)$ & $2(16.7 \%)$ & $4(33.3 \%)$ & $4(33.3 \%)$ & $4(33.3 \%)$ & $0(0 \%)$ \\
\hline \multicolumn{9}{|c|}{ Peripheral giant cell granuloma $(\mathrm{n}=19)$} \\
\hline Multinucleated giant cell & $4(21.1 \%)$ & $2(10.5 \%)$ & $7(36.8 \%)$ & $6(31.6 \%)$ & $2(10.5 \%)$ & $15(78.9 \%)$ & $2(10.5 \%)$ & $0(0 \%)$ \\
\hline Mononuclear cell & $13(68.4 \%)$ & $2(10.5 \%)$ & $3(15.8 \%)$ & $1(5.3 \%)$ & $9(47.4 \%)$ & $9(47.4 \%)$ & $1(5.3 \%)$ & $0(0 \%)$ \\
\hline Endothelial cell & $7(36.8 \%)$ & $4(21.1 \%)$ & $6(31.6 \%)$ & $2(10.5 \%)$ & $0(0 \%)$ & $7(36.8 \%)$ & $12(63.2 \%)$ & $0(0 \%)$ \\
\hline
\end{tabular}

Table V: Comparison of CD 68 intensity score of mononuclear cells among groups

\begin{tabular}{lcccc}
\hline Intensity score & $\begin{array}{c}\text { Aggressive CGCG } \\
(\mathbf{n}, \mathbf{\%})\end{array}$ & $\begin{array}{c}\text { Non-aggressive CGCG } \\
(\mathbf{n}, \mathbf{\%})\end{array}$ & PGCG (n, \%) & p-value \\
\hline 0 & $3(30 \%)$ & $0(0 \%)$ & $2(10.5 \%)$ & 0.016 \\
\hline 1 & $2(20 \%)$ & $1(8.3 \%)$ & $9(47.4 \%)$ & \\
\hline 2 & $5(50 \%)$ & $9(75 \%)$ & $7(36.8 \%)$ & \\
\hline 3 & $0(0 \%)$ & $2(16.7 \%)$ & $1(5.3 \%)$ & \\
Total & 10 & 12 & 19 & \\
Mean rank & 17.2 & 28.63 & 18.18 & \\
Median & 1.5 & 2.0 & 1.0 & \\
\hline
\end{tabular}

CGCG: Central giant cell granuloma, PGCG: Peripheral giant cell granuloma 
Table VI: Comparison of endothelial cells CD 68 Proportion score among groups

\begin{tabular}{lcccc}
\hline Proportion score & $\begin{array}{c}\text { Aggressive CGCG } \\
(\mathbf{n}, \mathbf{\%})\end{array}$ & $\begin{array}{c}\text { Non-aggressive CGCG } \\
(\mathbf{n}, \mathbf{\%})\end{array}$ & PGCG (n, \%) & p-value \\
\hline 0 & $3(30 \%)$ & $5(41.7 \%)$ & $1(5.3 \%)$ & 0.016 \\
\hline 1 & $4(40 \%)$ & $6(50 \%)$ & $9(47.4 \%)$ & \\
\hline 2 & $2(20 \%)$ & $1(8.3 \%)$ & $5(26.3 \%)$ & \\
\hline Total & $1(10 \%)$ & $0(0 \%)$ & $4(21.1 \%)$ & \\
Mean rank & 10 & 12 & 19 & \\
Median & 19.5 & 14.29 & 26.3 & \\
\hline
\end{tabular}

CGCG: Central giant cell granuloma, PGCG: Peripheral giant cell granuloma

Table VII: Comparison of endothelial cells factor VIII-RA intensity score among groups

\begin{tabular}{lcccc}
\hline Intensity score & $\begin{array}{c}\text { Aggressive CGCG } \\
(\mathbf{n}, \boldsymbol{\%})\end{array}$ & $\begin{array}{c}\text { Non-aggressive CGCG } \\
(\mathbf{n}, \mathbf{\%})\end{array}$ & PGCG (n, \%) & p-value \\
\hline 0 & $4(40 \%)$ & $4(33.3 \%)$ & $0(0 \%)$ & 0.004 \\
\hline 1 & $5(50 \%)$ & $4(33.3 \%)$ & $7(36.8 \%)$ & \\
\hline 2 & $1(10 \%)$ & $4(33.3 \%)$ & $12(63.2 \%)$ & \\
\hline Total & $0(0 \%)$ & $0(0 \%)$ & $0(0 \%)$ & \\
Mean rank & 10 & 12 & 19 & \\
Median & 13.35 & 18.00 & 26.92 & \\
\hline
\end{tabular}

CGCG: Central giant cell granuloma, PGCG: Peripheral giant cell granuloma

Vk et al. reported less CD68 positive MGCs in CGCG compared with PGCG but we did not find any significant difference between the groups (17). This can be attributed to the smaller sample size and evaluation of CGCG separately in two subtypes.

Despite no significant difference of CD68 expression in MCs among groups, positive CD68 MCs in aggressive CGCG was less than in non-aggressive CGCG and PGCG, whih was in agreement with the Syrio et al. study (12).

Moreover, the intensity score of CD68 in non-aggressive CGCG was significantly higher than aggressive CGCG. Taken together, these findings suggest that there may be a correlation between CD68 proportion and intensity score of MCs and the behavior or aggressiveness of the lesions.

Most of the researchers evaluated CD31, CD34 and VEGF expression as angiogenic markers in giant cell lesions $(7,13,28,29)$.

A few studies analyzed factor VIII-RA as a vascularization marker in giant cell lesions $(13,18,24)$. The current study demonstrated factor VIII-RA immunoreactivity in MGCs, MCs and endothelial cells in both PGCG and CGCG, implying MGCs and MCs as the sources of factor VIII-
RA in addition to endothelial cells. In contrast to previous study (13), we found no significant difference regarding percentage of factor VIII-RA positive endothelial cells among the groups. This discrepancy may be due to the evaluation method of factor VIII-RA expression. Matos et al. only focused on microvessel density and showed larger number of factor VIII-RA reactive vessels in PGCG. Also in that study, a negative correlation between VEGF expression and microvessel density in CGCG was observed, supporting the function of VEGF in osteoclastogenesis. On the other hand, possible interaction of factor VIII-RA in osteoclastogenesis through regulating OPG, RANK and RANK-L may be present. Baud'huin et al. (16) examined the role of factor VIII-RA on osteoclastogenesis using a cellular model. They concluded that the interaction between factor VIII-RA and OPG can cause inhibition of RANK-L induced osteoclastogenesis. Considering the significance of OPG, RANK and RANK-L as essential osteoclast formation components $(30,31)$, further attempts to clarify the role and correlation of factor VIII-RA with osteoclastogenesis may lead to a new treatment modality in giant cell lesions.

One of the most important findings in the present study was prominent factor VIII-RA immunoexpression in capillary like blood vessels in the periphery of the lesions. 
Furthermore, the morphology of the reactive blood vessels was completely different and slit-like in the center.

In line with present study, ultrastructural analysis of the microvasculature of giant cell granuloma showed a remarkable difference between the blood vessels of periphery and those deeper within the lesion around MGCs. Blood vessels of the periphery were lined with endothelial cells and basal lamina, thus presenting mature and normal blood vessels despite the central blood vessels (18). In accordance with these finding, Quindere et al. indicated a lack of collagen IV expression in blood vessels deeper within the lesion confirming the existence of a poorly formed vascular structure (13). However, Dewsnup et al. evaluated CD34 staining in giant cell lesions and no apparent difference was observed between the central and peripheral portion (28). Interestingly, we found that endothelial cells in PGCG stained intensely with factor VIII-RA. This may represent the reactive process of PGCG, targeting higher production of pro-angiogenic factors and greater inflammatory reaction.

In conclusion, the results of present study supported the histiocyte / macrophage nature of MGCs and MCs. Furthermore, overexpression and high intensity score of CD68 in MCs and high intensity score of factor VIII-RA in endothelial cells represent less aggressive behavior in CGCG.

\section{ACKNOWLEDGMENT}

This research is extracted from undergraduate thesis by Dr.Poursafar, which was successfully completed under the supervision of Dr. Sargolzaei and Dr. Taghavi, Department of Oral Pathology, Dental School, Shahid Beheshti University of Medical Sciences, Tehran, Iran, which was supported by research deputy of Dental School, Shahid Beheshti University of Medical Sciences, Tehran, Iran (Code number 12846).

\section{CONFLICT of INTEREST}

The authors declare no conflict of interest.

\section{REFERENCES}

1. Tobon-Arroyave SI, Mideros-Simarra SM, Castano-Ramirez LM, Florez-Moreno GA, Isaza-Guzman DM. Overexpression of matrix metalloproteinase (MMP)-1 and -9 in central giant cell lesions of the jaws: Implications for clinical behavior. Oral Surg Oral Med Oral Pathol Oral Radiol Endod. 2010;110:755-63.

2. Sarode SC, Sarode GS. Cellular cannibalism in central and peripheral giant cell granuloma of the oral cavity can predict biological behavior of the lesion. J Oral Pathol Med. 2014;43:45963.
3. Peacock ZS, Jordan RC, Schmidt BL. Giant Cell Lesions of the Jaws: Does the level of vascularity and angiogenesis correlate with behavior? J Oral Maxillofac Surg. 2012;70:1860-6.

4. Schütz P, El-Bassuoni KH, Munish J, Hamed HH, Padwa BL. Aggressive central giant cell granuloma of the mandible. J Oral Maxillofac Surg. 2010;68:2537-44.

5. Papanicolaou P, Chrysomali E, Stylogianni E, Donta C, Vlachodimitropoulos D. Increased TNF-alfa, IL-6 and decreased IL-1beta immunohistochemical expression by the stromal spindle-shaped cells in the central giant cell granuloma of the jaws. Med Oral Patol Oral Cir Bucal. 2012;17:56-62.

6. Amaral FR, Bernardes VF, Duarte AP, Pereira NB, Vasconcelos AC, Gomez RS, Gomes CC. Quantitative expression analysis of apoptotic/antiapoptotic genes and association with immunolocalization of BAX and BCL-2 in peripheral and central giant cell lesions of the jaws. Tumour Biol. 2011;32:997-1003.

7. Aragão Mdo S, Piva MR, Nonaka CF, Freitas Rde A, de Souza LB, Pinto LP. Central giant cell granuloma of the jaws and giant cell tumor of long bones: An immunohistochemical comparative study. J Appl Oral Sci. 2007;15:310-6.

8. Holness CL, Simmons DL. Molecular cloning of CD68, a human macrophage marker related to lysosomal glycoproteins. Blood.1993;81:1607-13.

9. Regezi JA, Zarbo RJ, Lloyd RV. Muramidase, alpha -1 antitrypsin, alpha -1 antichymotrypsin, and S-100 protein immunoreactivity in giant cell lesion. Cancer. 1987;59:64-8.

10. Bonetti F, Pelosi G, Martignoni G, Mombello A, Zamboni G, Pea M, Scarpa A, Chilosi M. Peripheral giant cell granuloma: Evidence for osteoclastic differentiation. Oral Surg Oral Med Oral Pathol. 1990;70:471-5.

11. Torabinia N, Razavi SM, Shokrolahi Z. A comparative immunohistochemical evaluation of CD68 and TRAP protein expression in central and peripheral giant cell granulomas of the jaws. J Oral Pathol Med. 2011;40:334-7.

12. Syrio NFL, Faria DR, Gomez RS, Gollob KJ, Dutra WO, Souza PE. IL-10 and IL-10 receptor overexpression in oral giant cell lesions. Med Oral Patol Oral Cir Bucal. 2011;16:488-92.

13. Matos FR, Nonaka CF, Miguel MC, Galvao HC, de Souza LB, Freitas Rde A. Immunoexpression of MMP-9, VEGF, and vWF in central and peripheral giant cell lesions of the jaws. J Oral Pathol Med. 2011;40:338-44.

14. Badawi MA, Abouelfadl DM, El-Sharkawy SL, El-Aal WE, Abbas NF. Tumor-Associated Macrophage (TAM) and angiogenesis in human colon carcinoma. Open Access Maced J Med Sci. 2015;3:209-14

15. Ivković-Kapicl T, Knelević-Usaj S, Panjković M, Mastilović K. Immunohistochemical analysis of angiogenesis in invasive ductal breast carcinoma with correlations to clinicopathological factor. Vojnosanit Pregl. 2006;63:635-42.

16. Baud'huin M, Duplomb L, Téletchéa S, Charrier C, Maillasson M, Fouassier M, Heymann D. Factor VIII-von Willebrand factor complex inhibits osteoclastogenesis and controls cell survival. J Biol Chem. 2009;284:31704-13. 
17. Vk V, Hallikeri K, Girish HC, Murgod S. Expression of CD34 and CD68 in peripheral giant cell granuloma and central giant cell granuloma: An immunohistochemical analysis. J Oral Maxillofac Pathol. 2014;18:341-8.

18. Lim L, Gibbins JR. Immunohistochemical and ultrastructural evidence of a modified microvasculature in the giant cell granuloma of the jaws. Oral Surg Oral Med Oral Pathol Oral Radiol Endod. 1995;79:190-8.

19. Vered M, Buchner A, Dayan D. Giant cell granuloma of the jawbones-a proliferative vascular lesion? Immunohistochemical study with vascular endothelial growth factor and basic fibroblast growth factor. J Oral Pathol Med. 2006;35:613-9.

20. Florez-Moreno GA, Henao-Ruiz M, Santa-Saenz DM, Castaneda-Pelaez DA, Tobon-Arroyave SI. Cytomorphometric and immunohistochemical comparison between central and peripheral giant cell lesions of the jaws. Oral Surg Oral Med Oral Pathol Oral Radiol Endod. 2008;105:625-32.

21. Liu B, Yu SF, Li TJ. Multinucleated giant cells in various forms of giant cell containing lesions of the jaws express features of osteoclasts. J Oral Pathol Med. 2003;32:367-75.

22. Souza PE, Mesquita RA, Gomez RS. Evaluation of p53, PCNA, Ki-67, MDM2 and AgNOR in oral peripheral and central giant cell lesions. Oral Dis. 2000;6:35-9.

23. Vered M, Nasrallah W, Buchner A, Dayan D. Stromal myofibroblasts in central giant cell granuloma of the jaws cannot distinguish between non-aggressive and aggressive lesions. J Oral Pathol Med. 2007;36:495-500.
24. Carvalho YR, Loyola AM, Gomez RS, Araújo VC. Peripheral giant cell granuloma. An immunohistochemical and ultrastructural study. Oral Dis. 1995;1:20-5.

25. Castro WH, Filho EC, de Souza PE, Gomez RS. Immunocytochemistry of fine-needle aspirates from central giant cell granuloma. Br J Oral Maxillofac Surg. 1998;36:301-3.

26. Neville BW, Damm DD, Allen CM, Bouquot JE. Oral \& maxillofacial pathology. $3^{\text {rd }}$ ed. Philadelphia: WB Saunders Co; 2009. 507-70, 613-77.

27. Flanagan AM, Nui B, Tinkler SM, Horton MA, Williams DM, Chambers TJ. The multinucleate cells in giant cell granulomas of the jaw are osteoclasts. Cancer. 1988;62:1139-45.

28. Dewsnup NC, Susarla SM, Abulikemu M, Faquin WC, Kaban LB, August M. Immunohistochemical evaluation of giant cell tumors of the jaws using CD34 density analysis. J Oral Maxillofac Surg. 2008;66:928-33.

29. Susarla SM, August M, Dewsnup N, Faquin WC, Kaban LB, Dodson TB. CD34 staining density predicts giant cell tumor clinical behavior. J Oral Maxillofac Surg. 2009;67:951-6.

30. Fanourakis G, Lazaris AC, Krithinakis S, Tosios KI, Sklavounou A, Tseleni-Balafouta S. Expression of receptor activator of NFkappaB ligand and osteoprotegerin in peripheral giant cell granulomas of the jaws. J Oral Pathol Med. 2010;39:687-9.

31. Tobón-Arroyave S, Francogonzalez L, Isazaguzman D, Florezmoreno G, Bravovasquez T, Castanedapelaez D, Viecodurán B. Immunohistochemical expression of RANK, GRa and CTR in central giant cell granuloma of the jaws. Oral Oncol. 2005;41:480-8. 